\title{
Managerial skills of managers in public and private organizations of Udaipur city - An assessment
}

\author{
POOJA ARYA, HEMU RATHORE AND SUMAN SINGH
}

Received: 13.05.2017; Revised: 09.10.2017; Accepted: 23.10.2017

See end of the paper for authors' affiliations

\section{POOJA ARYA}

Department of Family Resource

Management, College of Home Science,

Maharana Pratap University of

Agriculture and Technology, UDAIPUR

(RAJASTHAN) INDIA

Email : parya090@gmail.com
ABSTRACT : A managerial skills what the manager uses to assist the organization in accomplishing its goals specifically a manager makes use of his/her own abilities, knowledge base, experiences and perspectives to increase the productivity. The present study was undertaken with the objective to study managerial skills of managers employed in public and private organizations. The study was carried out in Udaipur district of Rajasthan state. A sample of 60 managers i.e. 30 from public organizations and 30 from private organizations were selected randomly for the present study. Online questionnaire technique was used for data collection. The results revealed that public organization managers were excellent stress managers with score (38-65) of 73.3 per cent and while private organization managers had excellent time management skills i.e. 86.6 per cent, only one bank manager had average problem solving (3.3\%) and time management skills $(3.3 \%)$ in public organizations were found in one respondent engaged in bank organization. Public organization manager's managerial skill ranged from average to excellent while managers in private organization it was good to excellent. Managers of private organization were having better managerial skills than public organization managers.

KEY WORDS: General management, Problem solving, Time management, Decision making, Interpersonal communication skills, Motivation, Stress management

-HOW TO CITE THIS PAPER : Arya, Pooja, Rathore, Hemu and Singh, Suman (2017). Managerial skills of managers in public and private organizations of Udaipur city - An assessment. Asian J. Home Sci., 12 (2) : 458-462, DOI: 10.15740/HAS/AJHS/12.2/458-462. 